УДК 334.021

DOI https://doi.org/10.32851/2708-0366/2020.4.24

Ющенко Н.Л.

кандидат економічних наук, доцент,

Хмельницький національний університет ORCID: https://orcid.org/0000-0001-5213-8341

Yushchenko Nadiia

Khmelnytskyi National University

\title{
МЕТОДИ ОЦІНКИ РИЗИКІВ ДЕРЖАВНО-ПРИВАТНОГО ПАРТНЕРСТВА В ТЕПЛОЕНЕРГЕТИЦІ ТА ЗАХОДИ ДЛЯ ЛІКВІДАЦІЇ НАСЛІДКІВ ЇХ ВИНИКНЕННЯ
}

\section{RISK ASSESSMENT METHODS OF PUBLIC-PRIVATE PARTNERSHIP IN HEAT POWER INDUSTRY AND MEASURES TO ELIMINATE THEIR CONSEQUENCES}

\begin{abstract}
Процес управління ризиками, щео триває протягом здійснення державно-приватного партнерства, передбачає разом з виявленням ризиків, визначенням шляхів запобігання їх виникненню, ліквідацією негативних наслідків і передачею ризиків, включаючи страхування, прийняттям ризиків їх оиінку. Стаття присвячена дослідженню державного впливу на розвиток державно-приватного партнерства в енергетиці України та систематизаиії методів якісної оцінки (оцінка ймовірності настання подї, дії або бездіяльності та ступеня iï впливу, шо визначається як висока, середня або низька) та етапам проведення аналізу чутливості, методу Монте-Карло, варіантам сиенарного аналізу за кількісного оцінювання ризиків, щуо супроводжують співробітництво держави та бізнесу у сферах виробництва, транспортування та постачання теплової енергії $і$ гарячого водопостачання, принципам $i$ методам управління ризиками проєктів державно-приватного партнерства.
\end{abstract}

Ключові слова: аналіз чутливості, державно-приватне партнерство, комунальне підприємство, метод Монте-Карло, ризик, сиенарний аналіз, теплопостачання, якісна оиінка.

Прочесс управления рисками, продолжающийся в течение осуществления государственно-частного партнерства, предусматривает совместно с выявлением рисков, определением путей предупреждения их возникновения, ликвидацией негативных последствий и передачей рисков, включая страхование, принятием рисков их оценку. Статья посвящена исследованию государственного влияния на развитие государственно-частного партнерства в энергетике Украины и систематизации методов качественной оченки (оценка вероятности наступления события, действия либо бездействия и степени его влияния, определяемой как высокая, средняя или низкая) и этапам проведения анализа чувствительности, метода Монте-Карло, вариантам сценарного анализа при количественном оценивании рисков, сопровождающих сотрудничество государства и бизнеса в сферах производства, транспортировки и снабжения тепловой энергии и горячего водоснабже- 
ния, принципам и методам управления рисками проектов государственно-частного партнерства.

Ключевые слова: анализ чувствительности, государственно-частное партнерство, коммунальное предприятие, метод Монте-Карло, риск, сиенарный анализ, теплоснабжение, качественная оченка.

In the field of utilities that provide services of general economic interest in Ukraine (ensure the viability of the city), the goal should be the use of public-private partnership instruments to attract strategic investors, with the prospect of privatizing enterprises that are not a natural monopoly. The process of risk management, continuing during the implementation of public-private partnership, provides, together with the identification of risks, determination of ways to prevent their occurrence, elimination of negative consequences and transfer of risks, including insurance, acceptance of risks, their assessment. We are talking about obtaining permits and licenses, operating risks, design and construction (reconstruction, improvement, and repair), financial and macroeconomic, social and political, other unforeseen circumstances that have a high level of impact. The article is devoted to the study of the state influence on the development of public-private partnerships in the energy sector of Ukraine and the systematization of qualitative methods (assessment of the probability of the occurrence of an event, action or inaction and the degree of its impact, defined as high, medium or low) and the stages of sensitivity analysis, the Monte Carlo method, scenarios analysis options for quantitative assessment of risks accompanying cooperation between the state and business in the production, transportation and supply of heat energy and hot water supply, principles and methods of risk management that have a significant impact on the decision to implement a public-private partnership or on its implementation. In particular, attention is paid to the statistical method, which consists in determining the level of threat of a risk, depending on the degree of probability of its occurrence; the expediency of costs, indicating the determination of the level of threat of the risk of exceeding the amount of funds that are planned to be spent during the fulfillment of the terms of the contract, in comparison with the previously established and agreed upon with the partners; expert assessment, which allows a group of experts to assess risks and, based on the results of such an assessment, determine the risk with the highest level of threat of its occurrence.

Key words: sensitivity analysis, public-private partnership, utility company, Monte Carlo method, risk, scenario analysis, heat supply, qualitative assessment.

Постановка проблеми. Вибравши демократичний напрям розвитку, Україна задекларувала побудову фінансово сильного й незалежного місцевого самоврядування. Одним з важливих завдань органу місцевого самоврядування для забезпечення комфортних умов проживання та перебування громадян на відповідній території $є$ необхідність здійснення видатків на утримання та розвиток інфраструктури відповідних населених пунктів, що викликає необхідність за рахунок коштів місцевих бюджетів фінансувати роботи з надання життєво необхідних послуг населенню та з ремонту й утримання об'єктів інфраструктури, які мають бути спрямовані на забезпечення та збереження їх технічного та естетичного стану, підвищення експлуатаційних якостей та продовження їх строків служби. В умовах суспільно-політичних та економічних викликів виконати це завдання без достатньої підтримки з боку держави або неурядових організацій видається усе важче. Впродовж багатьох років на зазначені цілі через обмеженість фінансових ресурсів у органів місцевого самоврядування на житлово-комунальне господарство, зокрема на теплові мережі, в місцевих бюджетах планують мізерні кошти. Переважно за останні роки це видатки на заходи з упередження аварій та запобігання техногенним катастрофам на аварійних об'єктах. Перш за все задля економії коштів планують видатки на оплату праці з нарахуваннями та на оплату комунальних послуг та енергоносіїв. Решту видатків, зокрема для вжиття заходів 3 розвитку інфраструктури та підтримки економіки, органам місцевого самоврядування планують з урахуванням наявних коштів та необхідності їх забезпечення.

Ринок централізованого теплопостачання в Україні насамперед складається з комунальних підприємств (КП), що виробляють, транспортують та постачають теплову енергію, надаючи послуги з опалення житлових будинків та гарячого водопостачання, 
а також належать до підприємств, що надають послуги загального економічного інтересу, забезпечення доступу до яких є функцією муніципалітету згідно із законодавством [1]. Інфраструктура зношена та малоефективна, що призводить до низької якості обслуговування, значних втрат енергії та витрат на утримання. Діючі тарифи на ці послуги не покривають фактичних витрат підприємств. Більш того, задля не підвищення тарифів у їх структурі відсутня інвестиційна складова частина. Як наслідок, фінансові показники комунальних теплопостачальних підприємств створюють потребу у фінансовій допомозі з місцевих бюджетів органів місцевого самоврядування та ведуть до накопичення боргу за постачання природного газу перед національною нафтогазовою компанією НАК «Нафтогаз України».

Хронічний дефіцит фінансових ресурсів, який унеможливлює виконання повною мірою покладених на місцеве самоврядування в Україні функцій і завдань, є однією 3 його найбільш болючих проблем. Потенційними джерелами залучення ресурсів для територіальної громади разом з міжнародними програмами фінансування проєктів на засадах співфінансування з органами місцевого самоврядування; продажом земельних ділянок або прав на них на конкурентних засадах; самооподаткуванням; місцевими запозиченнями; тим, що орган місцевого самоврядування може одержати позику на покриття тимчасового касового розриву; участю органів місцевого самоврядування в реалізації інвестиційних проєктів на умовах співфінансування з іншими суб'єктами (державою, іншими органами місцевого самоврядування, територіальною громадою) $€$ застосування державно-приватного партнерства (концесія, управління майном, спільна діяльність, змішане) на місцевому рівні [2, с. 305-328].

Аналіз останніх досліджень і публікацій. Численним аспектам управління ризиками державно-приватного партнерства присвячені дослідження таких науковців, як Н. Бабяк [3], Ю. Соколов, В. Маслова [4], К. Фарнелл [5]. Водночас потребують подальшого дослідження принципи та методи управління ризиками проєктів державно-приватного партнерства, застосування яких дасть змогу виявляти, стримувати та знижувати ризики, а також вживати превентивних заходів в інтересах проєкту.

Формулювання цілей статті. Метою статті є дослідження державного впливу на розвиток державно-приватного партнерства в енергетиці України та систематизація методів якісної та кількісної оцінки ризиків, що супроводжують співробітництво держави та бізнесу у сферах виробництва, транспортування та постачання теплової енергії і гарячого водопостачання.

Виклад основного матеріалу. Енергоефективна модернізація та технічне переоснащення об’єктів теплозабезпечення в умовах реформи децентралізації в Україні мають базуватися на такій формі взаємодії бізнесу і влади, як державно-приватне партнерство [6], що є привабливим (табл. 1) для місцевого рівня у сфері виробництва, транспортування й постачання тепла, а також є потенційним джерелом залучення ресурсів для територіальної громади. Його здійснення має передбачати виконання органами місцевого самоврядування однієї або кількох таких функцій, як проєктування, фінансування, будівництво, відновлення (реконструкція, модернізація), експлуатація, обслуговування.

Трактування сутності державно-приватного партнерства (ДПП) дає змогу його ідентифікувати як співробітництво між державою, територіальними громадами в особі відповідних державних органів влади й органів місцевого самоврядування (державними партнерами) та юридичними особами, крім державних і комунальних підприємств, або фізичними особами - підприємцями (приватними партнерами), що здійснюється на основі договору в порядку, встановленому Законом [7]. При цьому його основними ознаками є забезпечення вищих техніко-економічних показників ефективності діяльності, довготривалість відносин (5-50 років), передача приватному партнеру частини ризиків у процесі здійснення ДПП, внесення приватним партнером інвестицій в об'єкти партнерства $з$ джерел, не заборонених законодавством. 
Таблиця 1

\section{Переваги державно-приватного партнерства для органів місцевого самоврядування й приватного бізнесу}

\begin{tabular}{|c|c|}
\hline $\begin{array}{c}\text { Переваги для органів місцевого } \\
\text { самоврядування }\end{array}$ & Переваги для приватного бізнесу \\
\hline $\begin{array}{l}\text { - скорочення витрат на надання послуг; } \\
\text { - активізація інвестиційної діяльності; } \\
\text { - ефективне управління майном; } \\
\text { - економія бюджетних коштів; } \\
\text { - використання досвіду приватного бізнесу; } \\
\text { - оптимізація розподілу ризиків; } \\
\text { - підвищення ефективності інфраструктури; } \\
\text { - розвиток форм проєктного фінансування; } \\
\text { - рівний діалог між владою і бізнесом; } \\
\text { - збереження та створення робочих місць. }\end{array}$ & $\begin{array}{l}\text { - залучення бюджетних коштів до проєкту; } \\
\text { - доступ до раніше закритих сфер економіки } \\
\text { (ЖКГ, інфраструктура тощо); } \\
\text { - розширення можливостей отримання } \\
\text { пільгових кредитів під державні гарантії від } \\
\text { фінансових установ на довгий період; } \\
\text { - підвищення статусу проєкту через участь } \\
\text { державного партнера; } \\
\text { - позитивний імідж у суспільстві; } \\
\text { - оптимізація розподілу ризиків проєкту. }\end{array}$ \\
\hline
\end{tabular}

У рамках ДПП можуть укладатися договори про концесію, спільну діяльність та інші договори. При цьому його об’єктами можуть бути наявні, зокрема відтворювані (шляхом реконструкції, модернізації, технічного переоснащення) об'єкти; створювані чи придбані об'єкти. Передача об'єктів, що перебувають у державній або комунальній власності, не зумовлює перехід права власності на ці об'єкти до приватного партнера. Такі об'єкти підлягають поверненню державному партнеру після припинення дії договору державно-приватного партнерства.

Пропозиції про здійснення ДПП щодо об’єктів комунальної власності готуються відповідними органами місцевого самоврядування або особами, які можуть бути приватними партнерами, а також подаються на розгляд сільських, селищних, міських, районних чи обласних рад або до уповноважених ними органів. При цьому важливо провести аналіз ефективності його здійснення шляхом обгрунтування соціально-економічних та екологічних наслідків, порівняння основних показників реалізації проєкту (рентабельності, рівня витрат, якості послуг тощо), виявлення ризиків, визначення форми реалізації.

Така форма взаємодії бізнесу й влади має низку джерел фінансування:

1) фінансові ресурси приватного партнера;

2) фінансові ресурси, запозичені в установленому порядку;

3) кошти державного та місцевих бюджетів;

4) інші джерела, не заборонені законодавством.

Рішення про здійснення ДПП щодо об'єктів комунальної власності, проведення конкурсу з визначення приватного партнера та затвердження результатів приймаються місцевими радами. Визначення приватного партнера для укладення договору в рамках державно-приватного партнерства здійснюється виключно на конкурсних засадах (рис. 1). Порядок проведення конкурсу з визначення приватного партнера для здійснення ДПП щодо комунальної власності встановлюється Кабінетом Міністрів України [8].

Укладення договору здійснюється органом, який прийняв рішення про здійснення державно-приватного партнерства 3 переможцем конкурсу.

Під час проведення аналізу ефективності здійснення ДПП, прийняття рішень про його здійснення, розподілу ризиків між державним і приватним партнерами на кожному етапі здійснення державно-приватного партнерства, укладення договору між ними застосовується методика виявлення ризиків здійснення ДПП, їх оцінювання та визначення форми управління ними [9]. Такими ризиками можуть бути політичні, фінансові, екологічні, пов'язані з впливом зовнішніх обставин, що не залежать від 
волі партнерів, або невиконанням партнерами умов договору (табл. 2). Всі ризики підлягають якісному оцінюванню, під час якого визначаються причини й фактори, що впливають на ризики, а ті ризики, що впливають на зміну показників здійснення ДПП (чиста приведена вартість, внутрішня норма рентабельності, період окупності проєкту тощо [10]), підлягають також кількісному оцінюванню.

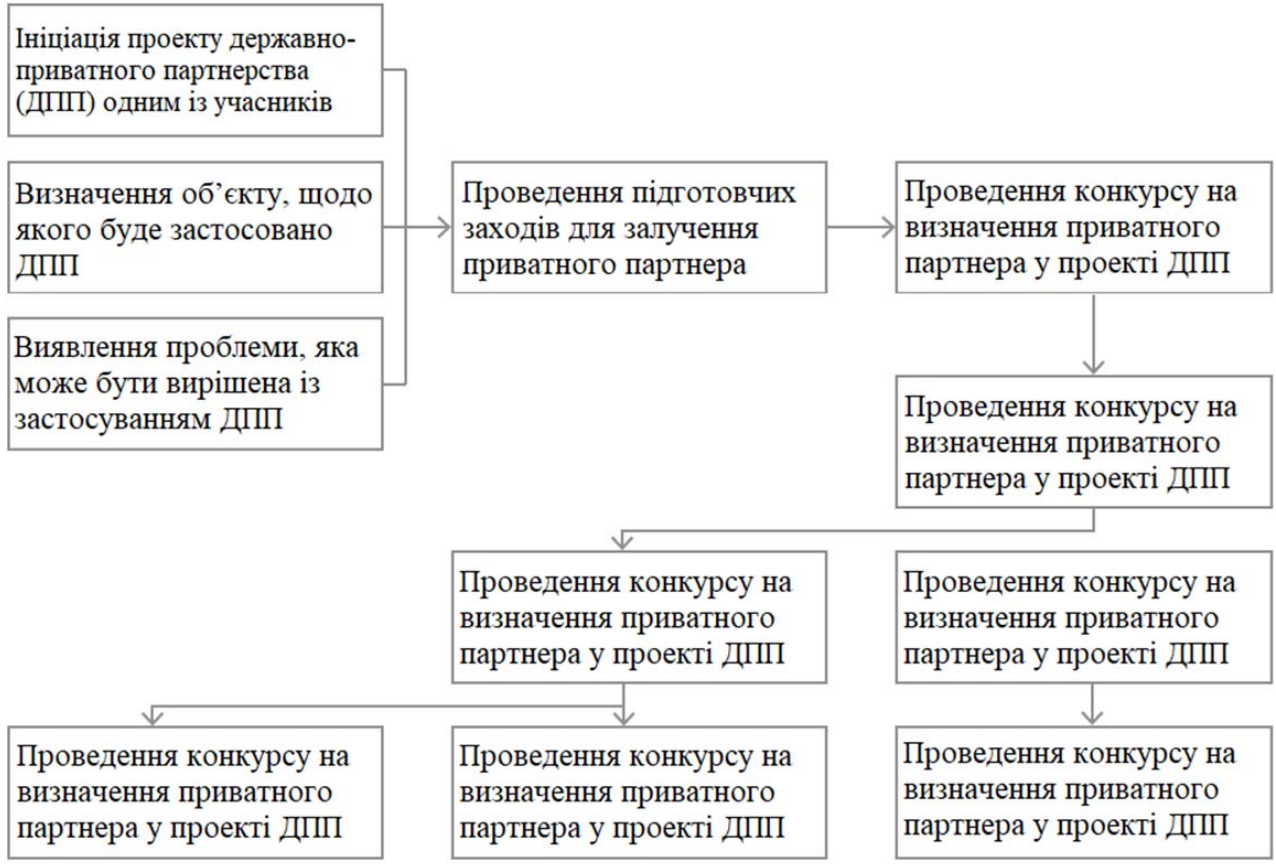

Рис. 1. Загальна схема послідовності реалізащії проєктів державно-приватного партнерства в Україні

Ризик оцінюється на основі історичних даних, прийнятих технічних моделей або експертних висновків. Вибір належного методу проведення оцінювання (або поєднання методів) залежить від конкретного виду ризику. Будь-який метод проведення кількісного оцінювання ризику має використовуватися з урахуванням способу визначення конкретного грошового потоку в базовій фінансовій моделі. Для проведення кількісного оцінювання ризиків застосовуються такі методи, як аналіз чутливості, сценарний аналіз, метод Монте-Карло.

Під час проведення аналізу чутливості визначаються основні фактори ризиків, що можуть привести до зміни показників здійснення державно-приватного партнерства (чиста приведена вартість (NPR), внутрішня норма рентабельності (IRR), період окупності проєкту (РВР) тощо)). Шляхом послідовної зміни основних факторів ризиків перевіряється їх вплив на базові показники здійснення державно-приватного партнерства в перспективі.

Аналіз чутливості проводиться за такими етапами:

- визначення основних змінних, які впливають на значення чистої приведеної вартості (NPV);

- встановлення залежності чистої приведеної вартості (NPV) від основних змінних;

- розрахунок базової ситуації, а саме встановлення очікуваного значення чистої приведеної вартості (NPV) за очікуваних значень основних змінних; 
- зміна однієї з вхідних змінних на потрібну величину (відсотків); при цьому всі інші вхідні змінні мають фіксоване значення;

- розрахунок нового значення чистої приведеної вартості (NPV) та його зміни (відсотків);

- розрахунок критичних значень змінних та визначення найбільш чутливих із них;

- проведення аналізу одержаних результатів.

Таблиця 2

Ризики, які можуть виникнути в державно-приватному партнерстві

\begin{tabular}{|c|c|}
\hline Види ризиків & Характеристика \\
\hline $\begin{array}{l}\text { Пов’язані з впливом } \\
\text { зовнішніх обставин }\end{array}$ & $\begin{array}{l}\text { Виникнення форс-мажорних обставин; випадкове знищення майна або } \\
\text { його частини; істотна зміна економічної ситуації, що унеможливлює } \\
\text { виконання умов договору. }\end{array}$ \\
\hline $\begin{array}{l}\text { Соціальні та } \\
\text { політичні ризики, } \\
\text { заперечення або опір } \\
\text { з боку основних } \\
\text { зацікавлених сторін }\end{array}$ & $\begin{array}{l}\text { Примусове відчуження майна; внесення змін до податкового законо- } \\
\text { давства; застосування стандартів, якими встановлюються підвищені } \\
\text { вимоги до товарів (робіт, послуг); відмова у видачі дозвільних доку- } \\
\text { ментів. }\end{array}$ \\
\hline $\begin{array}{l}\text { Пов’язані з } \\
\text { невиконанням } \\
\text { партнерами умов } \\
\text { договору }\end{array}$ & $\begin{array}{l}\text { Несвоєчасне або неповне здійснення платежів; виконання робіт в об- } \\
\text { сязі, меншому, ніж передбачено договором, або неналежної якості; не- } \\
\text { додержання строків і порядку виконання робіт. }\end{array}$ \\
\hline Комерційні & $\begin{array}{l}\text { Неотримання прибутку; залучення інвестицій в обсязі, недостатньому } \\
\text { для виконання умов договору; здійснення непередбачуваних витрат; } \\
\text { неефективне управління майном; зміна умов договору. }\end{array}$ \\
\hline $\begin{array}{l}\text { Фінансові та } \\
\text { макроекономічні } \\
\text { ризики }\end{array}$ & $\begin{array}{l}\text { Наявність фінансування; фінансова здатність приватного партнера; ін- } \\
\text { фляція; зміна курсу гривні до іноземної валюти, яка використовується } \\
\text { для проведення розрахунків за договором; підвищення відсоткових } \\
\text { ставок за кредитами, наданими в рамках партнерства. }\end{array}$ \\
\hline $\begin{array}{l}\text { Ризики впливу } \\
\text { на навколишнє } \\
\text { природне } \\
\text { середовище }\end{array}$ & Заподіяння шкоди здоров’ю людей та довкіллю; техногенні аварії. \\
\hline
\end{tabular}

Джерело: сформовано на основі [9, додаток 1]

Критичне значення змінної - це значення, за якого чиста приведена вартість (NPV) дорівнює нулю.

Державно-приватне партнерство має зберігати фінансову стабільність навіть у разі негативного значення основної змінної. На основі отриманих даних визначаються найбільш прийнятні показники здійснення державно-приватного партнерства.

Під час аналізу чутливості, зокрема, має бути визначена ймовірність:

- перевитрат коштів у ході будівництва чи поліпшення об'єкта державно-приватного партнерства;

- перевитрат коштів у ході експлуатації об’ єкта державно-приватного партнерства;

- недоотримання доходів (коли ризик попиту буде віднесений до сфери відповідальності приватного партнера).

Сценарний аналіз передбачає визначення кількох варіантів (сценаріїв) здійснення державно-приватного партнерства та проведення їх порівняльного оцінювання. Сценарний аналіз проводиться за такими варіантами (сценаріями):

- очікуваний (найбільш імовірний), що передбачає успішність здійснення державно-приватного партнерства, коли умови його здійснення будуть такими, як заплановано; 
- оптимістичний, що передбачає те, наскільки вдалим буде здійснення державно-приватного партнерства, коли умови його здійснення будуть більш сприятливими, ніж заплановано;

- песимістичний, що передбачає те, наскільки невдалим буде здійснення державно-приватного партнерства, коли умови його здійснення будуть гіршими, ніж заплановано.

Державно-приватне партнерство має зберігати фінансову стабільність також у разі песимістичного варіанта (сценарію).

Метод Монте-Карло [11, с. 228] передбачає використання у фінансовій моделі розподілу ймовірностей для низки ризикових змінних (факторів ДПП) і дослідження їх відповідного сукупного впливу на вихідні показники ДПП. Кількісна оцінка ризиків із застосуванням методу Монте-Карло проводиться лише за допомогою спеціального програмного забезпечення.

Метод Монте-Карло передбачає таке:

- визначення інтервалів можливої зміни основних ризикових змінних проєкту, всередині яких ці змінні $є$ випадковими величинами;

- проведення всередині визначених інтервалів оцінки видів розподілу ймовірностей (нормальний, дискретний, пірамідальний, трикутний);

- визначення коефіцієнта кореляції між залежними змінними; багаторазовий (більш як 500 сценаріїв) розрахунок результативного показника, що дає змогу розділити частоти для чистої приведеної вартості (NPV);

- визначення ймовірності потрапляння результативного показника в той чи інший інтервал та перевищення мінімально допустимого значення.

Кожен ризик має бути віднесений до сфери відповідальності того з партнерів, який більш ефективно контролюватиме виникнення такого ризику, управлятиме ним та/або запобігатиме йому. Ризики можуть бути розподілені між державним і приватним партнерами у відповідному співвідношенні.

Для забезпечення управління ризиками, які віднесені частково або повністю до сфери відповідальності державного партнера, складається перелік ризиків, управління якими здійснює державний партнер (рис. 2). До переліку ризиків, управління якими здійснює державний партнер, додаються такі:

- план управління ризиками, у якому зазначаються момент виникнення ризику, конкретні заходи щодо запобігання його виникненню, дії у разі виникнення ризику, перелік осіб, відповідальних за здійснення відповідних заходів, способи проведення на постійній основі моніторингу та аналізу кожного з ризиків;

- відомості про результати кількісної оцінки для тих ризиків, що мають істотний монетарний вплив на державний або місцевий бюджет (ризиків, які можуть привести до виникнення додаткових зобов'язань державного або місцевого бюджету у майбутньому).

Партнери можуть вживати таких заходів для ліквідації наслідків виникнення ризиків:

- надання державної підтримки;

- використання додаткових коштів, необхідних для виконання умов договору, в обсязі, який визначається та погоджується партнерами;

- припинення виконання партнерами певної умови договору;

- перегляд умов договору у зв'язку з виникненням ризику, зокрема продовження терміну його дії;

- розірвання договору одним 3 партнерів 3 одночасним урегулюванням питання щодо відшкодування пов'язаних з цим збитків;

- зміна передбаченої договором тарифної політики щодо товарів, які виготовляються, робіт, які виконуються, та послуг, що надаються партнерами; 
- страхування від невиконання відповідним партнером умов договору внаслідок виникнення ризику.

\section{ПЕРЕЛІК}

ризиків здійснення державно-приватного партнерства, управління якими здійснюс державний партнер

\begin{tabular}{|c|c|c|c|c|c|}
\hline $\begin{array}{c}\text { Категорія } i \\
\text { підкатегорія } \\
\text { ризику }\end{array}$ & $\begin{array}{c}\text { Опис } \\
\text { ризику }\end{array}$ & Вплив ризику & $\begin{array}{c}\text { Рівень/ступінь } \\
\text { впливу }\end{array}$ & $\begin{array}{c}\text { Ймовірність } \\
\text { настання }\end{array}$ & $\begin{array}{c}\text { Підхід до } \\
\text { ризикавління }\end{array}$ \\
ризиком \\
\hline
\end{tabular}

Примітки: 1. У графі «Категорія і підкатегорія ризику» зазначаються категорії і підкатегорії відповідно до додатка 1 до Методики виявлення ризиків здійснення державно-приватного партнерства, їх оцінки та визначення форми управління ними, а також категорії або підкатегорії, які не застосовуються до конкретного державно-приватного партнерства.

2. У графі «Опис ризику» стисло описується сутність ризику, який повністю або частково віднесений до сфери відповідальності державного партнера.

3. У графі «Вплив ризику» стисло описується результат впливу ризику, якщо ризик матеріалізується (тобто відповідна подія відбувається), а також зазначаються фізичні або юридичні особи, які ймовірно зазнають такого впливу.

4. У графі «Рівень/ступінь впливу» зазначається ступінь впливу ризику (низький, середній, високий).

5. У графі «Ймовірність настання ризику» зазначається імовірність настання ризику (низька, середня, висока).

6. У графі «Підхід до управління ризиком» стисло описується підхід, який державний партнер планує застосувати до управління ризиком.

\section{Рис. 2. Додаток 2 до Методики виявлення ризиків здійснення державно-приватного партнерства, їх оцінки та визначення форми управління ними}

Джерело: сформовано на основі [9]

У сфері енергетики, громадському житловому секторі та системах життєзабезпечення міст застосовують механізм ДПП США, Канада, Австралія, Іспанія, Нідерланди [12]. За свідченням зарубіжного досвіду, ДПП є одним з найбільш дієвих інструментів реалізації політики економічного розвитку та вирішення соціальних проблем територій. Узгодження інтересів між муніципалітетами і приватними структурами на умовах об'єднання фінансових, технологічних, організаційно-управлінських, кадрових та інших ресурсів забезпечує мультиплікативний ефект та подальші тенденції розвитку.

Після схвалення Концепції [6] ДПП не без труднощів розвивається в Україні. Так, для модернізації житлово-комунального господарства Міністерство розвитку громад та територій України спільно з Свропейським інвестиційним банком реалізовує Програму розвитку муніципальної інфраструктури України. Позики в рамках ДПП, крім централізованого теплопостачання, залучаються до таких сфер, як водопостачання та водовідведення, поводження з твердими побутовими відходами, енергоефективність будівель і зовнішнє освітлення населених пунктів [13]. Кінцевими бенефіціарами $\epsilon$ центральні, регіональні або місцеві органи влади, державні та комунальні підприємства і місцеві органи самоврядування, включаючи організації, які мають більшу частку державного чи комунального капіталу. Десять проєктів у сферах централізованого теплопостачання, енергоефективності будівель та зовнішнього освітлення отримали підтвердження від Європейського інвестиційного банку щодо можливості виділення коштів позики на їх фінансування. Щодо шести проєктів із зазначених підписано 
угоди про передачу коштів позики. За підтримки консультантів, відібраних Європейським інвестиційним банком, завершується підготовка тендерної документації щодо проєктів з високим ступенем готовності. До кінця 2020 р. планується оголосити тендери щонайменше за трьома проєктами у сферах водопостачання та водовідведення i централізованого теплопостачання [14].

Висновки. Як визначено Національною економічною стратегією 2030, енергетичний сектор України загалом потребує щонайменше \$25 млрд. до 2030 р. для забезпечення заміщення генеруючих потужностей, а також модернізації енергетичної інфраструктури. Тоді як у СС середній показник становить $32 \%$, в Україні 44\% енергії втрачаються під час перетворення та транспортування до кінцевого споживача. Зокрема, рівень зношеності інфраструктури в теплоенергетиці є критичним: 40\% теплових пунктів і 15,8\% загальної протяжності тепломереж перебувають в аварійному стані. Значна кількість ТЕС/ТЕЦ відпрацювала більше 50 років та буде виводитися з експлуатації з 2021 р. за невиконання природоохоронних заходів згідно 3 Національним планом скорочень викидів, що формує ризики балансування енергосистеми та виклики для міст, у яких теплова генерація була ключовим роботодавцем та формувала значні надходження до бюджету. Державно-приватне партнерство може бути основою модернізації об’єктів комунальної інфраструктури.

Відповідно до Національної економічної стратегії 2030, задля підвищення інституційної спроможності органів державної та місцевої влади передбачено розроблення структури централізованого управління державними і комунальними підприємствами, а саме Інституції централізованого управління та ії формування. Органи місцевого самоврядування повинні створити центри координації (проєктні центри або відділи) при органах місцевого самоврядування, що відповідатимуть за координацію реформування комунальної власності та за комунікацію з відповідальними державними органами. Центри координації на базі партнерства держави, бізнесу, науки й громадськості мають самостійно формувати стимули і важелі для залучення в регіон інвестицій для кардинальної зміни функціонування теплової генерації та тепломереж, сприяти розвитку місцевих енергетичних ініціатив, зокрема малого та середнього підприємництва в енергетичній сфері та енергетичних кооперативів, генерації та постачання електричної і теплової енергії з урахуванням регіональних особливостей, розвитку розподіленої генерації.

\section{Список використаних джерел:}

1. Про затвердження переліку послуг, що становлять загальний економічний інтерес. URL: https://zakon.rada.gov.ua/laws/show/420-2018-\%D0\%BF\#Tex (дата звернення: 09.12.2020).

2. Кириленко О., Малиняк Б., Письменний В., Русін В. Планування та управління фінансовими ресурсами територіальної громади / Асоціація міст України. Київ : ТОВ «ВI ЕН ЕЙ», 2015. $396 \mathrm{c}$.

3. Бабяк Н. Контролінг ризиків проєктів державно-приватного партнерства. Фінанси України. 2014. № 6. С. 95-111.

4. Соколов М., Маслова С. Управление рисками в проектах государственно-частного партнерства. Вестник Санкт-Петербургского университета. Серия «Менеджмент». 2013. Вып. 4. C. $100-124$.

5. Furnell C. Risk identification and risk allocation in project finance transactions. The University of Melbourne, May 2000. P. 1.

6. Концепція розвитку державно-приватного партнерства в Україні на 2013-2018 роки : Розпорядження Кабінету Міністрів України від 14 серпня 2013 р. № 739-p. URL: https://zakon.rada.gov.ua/laws/show/739-2013-\%D1\%80\#n8 (дата звернення: 09.12.2020).

7. Про державно-приватне партнерство : Закон України № 2404-VI зі змінами в редакції від 25 жовтня 2020 p. URL: https://zakon.rada.gov.ua/laws/show/2404-17\#Tехt (дата звернення: 09.12.2020).

8. Деякі питання організації здійснення державно-приватного партнерства : Постанова Кабінету Міністрів України від 11 квітня 2011 р. № 384 (зі змінами в редакції від 16 жовтня 
2020 р.). URL: https://zakon.rada.gov.ua/laws/show/384-2011-\%D0\%BF\#Text (дата звернення: 09.12.2020).

9. Методика виявлення ризиків здійснення державно-приватного партнерства, їх оцінки та визначення форми управління ними : Постанова Кабінету Міністрів України від 16 лютого 2011 р. № 232 в редакції від 16 вересня 2020 p. URL: https://zakon.rada.gov.ua/laws/show/232-2011$\%$ D0\%BF\#Техt (дата звернення: 09.12.2020).

10. Ющенко Н. Економіко-математичний інструментарій прийняття рішень в умовах невизначеності та/або ризику. Вісник Хмельницького національного університету. Серія «Економічні науки». 2017. № 5. С. 99-107.

11. Ющенко Н. Економіко-математичні моделі в управлінні та економіці : навчальний посібник. Чернігів : Чернігівський національний технологічний університет, 2016. 285 с.

12. Щодо розвитку державно-приватного партнерства як механізму активізації інвестиційної діяльності в Україні : аналітична записка. Сайт Національного інституту стратегічних досліджень. URL: https://niss.gov.ua/doslidzhennya/ekonomika/schodo-rozvitku-derzhavno-privatnogopartnerstva-yak-mekhanizmu-aktivizacii (дата звернення: 09.12.2020).

13. Фінансова угода між Україною та Європейським Інвестиційним Банком, проєкт «Програма розвитку муніципальної інфраструктури України». Документ № 971_020 в редакції від 31 березня 2020 p. URL: https://zakon.rada.gov.ua/laws/show/971_020\#Text (дата звернення: 09.12.2020).

14. Інформація щодо реалізації проєкту «Програма розвитку муніципальної інфраструктури України» від 1 жовтня 2020 р. Офіційний веб-сайт Міністерства розвитку громад та територій України. URL: https:/www.minregion.gov.ua/napryamki-diyalnosti/international-cooperation/spilniz-yevropeyskim-bankom-proekti/informacziya-shhodo-realizacziyi-proektu-programa-rozvytkumuniczypalnoyi-infrastruktury-ukrayiny (дата звернення: 09.12.2020).

\section{References:}

1. Pro zatverdzhennya pereliku poslug, shho stanovlyat' zagal'ny'j ekonomichny'j interes [On approval of the list of services of general economic interest]. Available at: https:/zakon.rada.gov.ua/ laws/show/420-2018-\%D0\%BF\#Tex (accessed 09 December 2020).

2. Ky'ry'lenko O., Maly'nyak B., Py's'menny'j V., Rusin V. (2015) Planuvannya ta upravlinnya finansovy'my' resursamy' tery'torial'noyi gromady' [Planning and management of financial resources of the territorial community]. Kyiv: VNA ENTERPRISE LLC. (in Ukrainian)

3. Babyak N. (2014) Kontroling ry'zy'kiv proektiv derzhavno-pry'vatnogo partnerstva [Risk control of public-private partnership projects]. Finance of Ukraine, no. 6, pp. 95-111.

4. Sokolov M., Maslova S. (2013) Upravlenie riskami v proektakh gosudarstvenno-chastnogo partnerstva [Risk management in public-private partnership projects]. Bulletin of St. Petersburg University. Series "Management”, vol. 4, pp. 100-124.

5. Furnell C. (2000) Risk identification and risk allocation in project finance transactions. The University of Melbourne, p. 1.

6. Cabinet of Ministers of Ukraine (2013) Order of the Cabinet of Ministers of Ukraine "The concept of development of public-private partnership in Ukraine for 2013-2018". Available at: https://zakon.rada.gov.ua/laws/show/739-2013-\%D1\%80\#n8 (accessed 09 December 2020).

7. The Verkhovna Rada of Ukraine (2017) The Law of Ukraine "On public-private partnership". Available at: https://zakon.rada.gov.ua/laws/show/2404-17\#Text (accessed 09 December 2020).

8. Cabinet of Ministers of Ukraine (2011) Resolution of the Cabinet of Ministers of Ukraine "Some issues of the organization of public-private partnership". Available at: https://zakon.rada.gov.ua/ laws/show/384-2011-\%D0\%BF\#Text (accessed 09 December 2020).

9. Cabinet of Ministers of Ukraine (2011) Resolution of the Cabinet of Ministers of Ukraine "Methods for identifying risks of public-private partnerships, their assessment and determining the form of their management". Available at: https://zakon.rada.gov.ua/laws/show/232-2011-\%D0\%BF\#Text (accessed 09 December 2020).

10. Yushhenko N. (2017) Ekonomiko-matematy'chny'j instrumentarij pry’jnyattya rishen' v umovax nevy'znachenosti ta/abo ry'zy'ku [Economic and mathematical tools for decision making in conditions of uncertainty and/or risk]. Bulletin of Khmelnytsky National University. Economic Sciences Series, no. 5, pp. 99-107. 
11. Yushhenko N. (2016) Ekonomiko-matematy'chni modeli v upravlinni ta ekonomici [Economic and mathematical models in management and economics: a textbook]. Chernihiv: Chernihiv National Technological University. (in Ukrainian)

12. Website of the National Institute for Strategic Studies. Regarding the development of public-private partnership as a mechanism for intensifying investment activities in Ukraine : analytical note. Available at: https://niss.gov.ua/doslidzhennya/ekonomika/schodo-rozvitku-derzhavno-privatnogo-partnerstva-yak-mekhanizmu-aktivizacii (accessed 09 December 2020).

13. Finansova ugoda mizh Ukrayinoyu ta Yevropejs'ky'm Investy'cijny'm Bankom proekt “Programa rozvy’tku municy’pal'noyi infrastruktury’ Ukrayiny'”. Dokument № 971_020 v redakciyi vid 31.03.2020 [Financial agreement between Ukraine and the European Investment Bank project "Municipal Infrastructure Development Program of Ukraine"]. Available at: https://zakon.rada.gov.ua/ laws/show/971_020\#Text (accessed 09 December 2020).

14. Official website of the Ministry of Community and Territories of Ukraine (2020) Information on the implementation of the project "Program for the development of municipal infrastructure of Ukraine”. Available at: https://www.minregion.gov.ua/napryamki-diyalnosti/international-cooperation/spilni-z-yevropeyskim-bankom-proekti/informaciya-shhodo-realizaciyi-proektu-programa-rozvytku-municzypalnoyi-infrastruktury-ukrayiny/ (accessed 09 December 2020). 